УдК 342.41

DOI https://doi.org/10.32837/apdp.v0i88.3051

Г. В. Берченко

\title{
РОЗВИТОК КОНСТИТУЦІЇ ШЛЯХОМ ЇЇ СУДОВОГО ТЛУМАЧЕННЯ ТА УСТАНОВЧА ВЛАДА
}

Традиційно, коли йдеться про внесення змін до конституції, ми маємо на увазі трансформацію її тексту. Водночас у п. 18. Доповіді про конституційні поправки CDL-AD (2010) 001 (ухвалено Венеціанською комісією на 81-му пленарному засіданні (Венеція, 11-12 грудня 2009 р.)) зазначено: «Істотний зміст конституції, звичайно, може бути змінено багатьма іншими способами - судовим тлумаченням, новими конституційними конвенціональностями, політичною адаптацією, втратою чинності, або нерегулярними (неправові й антиконституційні) засобами» .

Справді, було б надто формалістично вбачати конституцію в її текстуальному вираженні поза практикою застосування, тлумачення тощо. 3 огляду на позицію авторитетної європейської інституції, варто проаналізувати чинник тлумачення, який звичайно впливає на їі зміст, а зміна вже сформованого тлумачення і поготів.

Метою статті є з'ясування сутності розвитку конституції шляхом її тлумачення в аспекті співвідношення з концепцією установчої влади. Завдання статті такі: розкрити зміст різних концепцій щодо розвитку конституції, эї трансформації або ж зміною не внаслідок текстуальних змін; з'ясувати специфіку окремого повноваження Конституційного Суду України щодо офіційного тлумачення Конституції, висловити пропозиції щодо його вдосконалення; з'ясувати зв'язок судового тлумачення Конституції із концепцією установчої влади.

Щодо стану літератури в напрямі дослідженого питання, варто відзначити праці Г. Єллінека [1], А.М. Медушевського [2], П. Розанвалона [3], Р. Познера [4; 5], І. Сліденка [6] та інших науковців.

Для позначення впливу тлумачення на зміст конституції використовують різні терміни. І. Сліденко вживає термін «розвиток». На його думку, розвиток конституції здійснюється шляхом тлумачення її базових принципів, за критерієм «переваги/недоліки» тлумачення переважає над унесенням безпосередніх змін [6, с. 63]. Наявність конституційного контролю дозволяє шляхом тлумачення максимально наближувати її до виконавців, тобто сприяти реалізації. Саме так найоптимальнішим чином можуть забезпечуватися стабільність і гнучкість конституції. Потреба в постійних змінах зникає [6, с. 64].

На думку Г. Єллінека, конституції містять правові норми, а будь-яке право змінюється і розвивається шляхом закону або шляхом звичаєвого права, або, як стверджують одні й із чим сперечаються інші, шляхом права юристів. Учений розмежовував зміну тексту конституції, що здійснюється цілеспрямованими вольовими актами, та перетворення конституції - ті зміни, які залишають їі текст у попередньому вигляді та спричинені фактами, які не пов'язані безпосередньо з намірами здійснити такі зміни або з усвідомленням, що останнє обов'язково відбудеться [1, с. 4-5]. 
К. Гессе виокремлює «зміни конституції», «порушення конституції» $\mathrm{i}$ «конституційні відхилення». «Зміни конституції» - це формальні зміни її тексту. «Порушення» конституції відступ від тексту в окремих випадках (без зміни тексту), що вважалося допустимим в державній практиці Веймарської конституції за умови наявності необхідної для зміни конституції більшості. Під «конституційними відхиленнями» розуміється не зміна тексту як такого - він залишається незмінним, а конкретизація змісту конституційних норм, яка, особливо з огляду на широту і відкритість багатьох конституційних положень, може призвести за обставин, що змінюються, до різних результатів і, таким чином, сприяє «відхиленням» [7, с. 38].

М. Прело стверджує, що процес змін конституції з 1947 р. відбувався такими способами: шляхом тлумачення звичаєм або регламентуванням; шляхом видання різних органічних законів; шляхом перегляду тексту самої конституції [8, с. 356357]. Як бачимо, серед способів змін судове тлумачення не назване.

На думку В.В. Лемака, існують два важливі різновиди тлумачення конституції залежно від отриманого результату. Звичайне тлумачення має результатом розкриття змісту конституційного тексту, тоді як «конституційне конструювання» (“constitutional construction”) починається з розкриття змісту тексту та йде далі формулює, по суті, нову конституційну норму [9, с. 432].

Тлумачення можна вважати розшифровкою переданої інформації (і такий сенс цього слова є найменш проблематичним), розумінням, перекладом, поширенням, завершенням, перетворенням і навіть зміною акцентів. Конкретно цей термін означає лише те, що існує якийсь текст, він є авторитетним, і рішення має бути якось із ним пов' язане [4, с. 292].

Іноді тлумачення прямо називають знімною конституції. Коли суди тлумачать конституцію, вони не можуть не осмислювати її положення по-новому. Тому судове тлумачення є головною формою змін конституції [10, с. 112].

А.М. Медушевський прямо пише про зміни Конституції США шляхом тлумачення [2, с. 67]. Текст Конституції 1787 р. залишився практично незмінним (якщо не брати до уваги зміни, внесені поправками), проте за змістом вона не тільки не тотожна, але в деяких істотних питаннях радикально відрізняється від початкового розуміння. Конституція змінена тлумаченням так, що з її новим розумінням навряд чи погодилися б самі засновники [2, с. 72$]$.

Важливе питання про точний сенс поняття конституції: чи зводиться воно до тексту Основного закону, чи включає наступні авторитетні тлумачення, або має бути відкрито для раціональної інтерпретації з позицій здорового глузду в його сучасному розумінні. Важливим революційним кроком в інтерпретації Біблії стала спроба її раціональної критики в Новий час. Спіноза у своєму «Богословсько-політичному трактаті» порушив низку проблем, схожих із тими, які дискутуються сучасними конституціоналістами. Для встановлення точного сенсу священних законів він пропонував увести градацію відомостей про них, з огляду на їхню інформаційну достовірність. У зв'язку із цим він знаходив іманентну критику священних текстів (за їхнім історичним, логічним і лінгвістичним аналізом); думок пророків (справжні і приписувані їм), від них переходив до детального аналізу змісту кожного пророцтва, одкровення і дива (для чого давалися точні визначення цих 
понять і встановлювався ступінь достовірності свідчень про них). Він наполягав на необхідності дотримання граничної обережності, щоб «не змішати думку пророків та істориків з думкою Святого Духа і правдою речей». Отже, дилема сучасного конституціоналізму полягає в тому, щоб не підмінити дух або навіть текст конституції ї̈ неадекватним тлумаченням [2, с. 28].

Судова система відіграє роль тлумача закону, вони є «правом, що промовляє». У сучасних ліберальних демократіях обов'язкова для виконання конституція заміщує собою божественний чи природний закон, давній закон чи звичаєве право античних Греції і Риму та Середньовіччя, забезпечує правовий контроль над владою [11, с. 66].

Тут варто згадати думку Карла Шмітта про те, що всі точні поняття сучасного вчення про державу являють собою секуляризовані теологічні поняття [12, с. 57]. Вочевидь, те саме стосується тлумачення права і конституції.

Згідно із західними теоретичними підходами, концепція конституції містить не лише позитивний нормативно-правовий текст, але й фундаментальні принципи конституційного рівня. Вони являють собою певні конституційні вимоги до позитивного законодавства, які походять із природного права (принципи розумності, чіткості, справедливості, пропорційності верховенства права, цілеспрямованості, безпосереднього судового захисту прав та свобод людини тощо), можуть мати як писану, так і неписану форму, покликані інституціоналізувати ціннісні критеpiї визначення чинності нормативно-правових актів держави [13, с. 34].

За уважного вивчення конституційних норм важко не помітити їхньої важливої особливості - вони сформульовані у вигляді відкритого тексту, а отже, являють собою «порожні судини», які треба заповнювати конкретним змістом у процесі реалізації Конституції [13, с. 9]. Відкритість конституційного тексту не є недоліком конституційно-правового регулювання, а радше є його перевагою, що дає змогу наблизити Конституцію до умов суспільно-політичного життя та зробити її реальною, юридичною [13, с. 253].

Оскільки текст Конституції США не розкриває обсягу захисту того чи іншого права, Верховний Суд має змогу значно поширити або звузити його на власний розсуд. Досвід показує, що в захисті громадських свобод Суд не завжди поводиться однаково. Бачимо, що найбільша увага приділялася захистові свободи слова та преси, менша - захистові прав власності, мінімальна - підтриманню економічних прав. Текст Конституції не надає жодного натяку на такий розподіл, який цілковито є результатом суддівського тлумачення [15, с. 42-43].

Проте тут варто згадати критику концепції відкритого тексту. «Відкриту текстуру» мають не тільки норми конституції. За Гартом, загалом норми права мають цю властивість, унаслідок чого судді мають право ухвалювати й ухвалюють рішення на власний розсуд, створюють нові закони. Цьому опонує Рональд Дворкін, коли критикує Гарта. На думку Р. Дворкіна, обов'язком судді залишається, навіть у складних справах, з'ясувати, у чому полягають права обох сторін, а не винаходити заднім числом нові права [16, с. 120].

Варто пам'ятати і про тезу німецького конституціоналіста К. Гессе. Інтерпретація пов'язана із чимось передбачуваним. Тому межі інтерпретації конституції 
проходять там, де немає обов'язкових положень конституції, де закінчуються можливості свідомого розуміння тексту норм або де рішення очевидно суперечить тексту норми. Обов'язкові положення можуть водночас міститися і в усному конституційному праві. Оскільки усне конституційне право не повинно суперечити писаній конституції, це і є межею інтерпретації конституції, яку не можна перетинати. Ця межа є передумовою, що раціоналізує, стабілізує й обмежує владу функції конституції. Вона допускає можливість відхилення від конституції в результаті інтерпретації, але виключає можливість порушення конституції, відхилення від тексту в окремих випадках і зміни конституції. Там, де інтерпретатор виходить за межі конституції, він більше не інтерпретує, а змінює або порушує конституцію. В обох випадках йому перешкоджає в цьому чинне право. Навіть тоді, коли не знаходиться відповідного рішення проблеми, суддя, прив'язаний до конституції, не має вільного вибору. Такий стан речей лімітує «проблемне мислення» у рамках конституційного права [7, с. 53].

Ключову роль у тлумаченні конституції в тих країнах, де існує модель спеціалізованого конституційного контролю, відіграють конституційні суди. Проте, як відомо, Конституційний Суд України (далі - КСУ) відповідно до Конституції України здійснює низку повноважень, окремо зафіксовано повноваження щодо офіційного тлумачення Конституції України і щодо перевірки на відповідність Конституції України низки правових актів.

Здійснення обов'язкового тлумачення Конституції і законів закріплене в Азербайджані, Киргизстані, Молдові, Росії й Україні [17, с. 56]. Як зазначала свого часу Венеціанська комісія (висновок щодо проєкту Конституції України від 21 травня 1996 р. CDL-INF (96) 6 щодо тексту, затвердженого Конституційною комісією 11 березня 1996 р.), очевидним є те, що Конституційний Суд має тлумачити Конституцію, щоб дійти висновків, однак видається, що ухвалення офіційного тлумачення Конституції виходить за межі звичайних функцій судового органу. Тут варто було б передбачити, щоб Конституційний Суд міг надавати рекомендаційні висновки, коли тлумачить конституційні положення зі специфічної проблеми.

Як стверджувалося в попередньому висновку CDL-PI (2015) 016 від 24 липня 2015 р., відповідно до змін у частині правосуддя Конституційний Суд зберігає повноваження щодо «надання офіційного тлумачення Конституції України» (ст. 147 і ч. 2 пп. 1 п. 1 ст. 150), що суперечить попереднім рекомендаціям Венеціанської комісії (26 висновок Венеціанської комісії CDL-AD (2008) 029, п. 18).

У зв'язку із цим, як на мене, варто було б ще раз звернути увагу на повноваження щодо офіційного тлумачення Конституції України шляхом його вдосконалення і прив'язки до конкретних практичних проблем правозастосування або ж відмовитися від нього взагалі. Тлумачення Конституційним Судом має здійснюватися, проте казуально - під час розгляду конкретної справи, шляхом конституційного контролю.

Стосовно тлумачення конституції конституційними судами постає додаткова проблема - чим обгрунтовується легітимність відповідного тлумачення, якщо його кваліфікувати як розвиток конституції або ж навіть як фактичні зміни? 
Щодо правильного тлумачення конституції набуває актуальності проблема суверенітету. Саме тому, що в умовах дії прав і свобод кожен має власне уявлення про неї, постає питання про те, хто ж дає остаточне тлумачення конституції, хто є її інтерпретатором [18, с. 225].

Як стверджує П. Розанвалон, установчу владу як пряме існування суверенітету народу не можна брати за норму демократичного життя [3, с. 161]. Він виокремлює електоральний народ, народ соціальний і народ-принцип. Народ-принцип цілком природно ототожнюється з ідеєю нації. Як абстрактна фігура суверенітету нація починає сприйматися тільки через освоєння та практичне застосування принципів, на яких вона грунтується. Отже, їй потрібен орган, щоби представляти їі. Саме цьому завданню відповідає нині конституційний суд. Конституційні суди гарантують ідентичність демократії як установи в часовій плинності. Необхідність такої плюралізації часових вимірів демократії лише збільшується в сучасних суспільствах, над якими дедалі більше тяжіє загроза короткочасної диктатури. Функція представництва принципів тим самим набуває підсиленого значення [3, с. 170-171].

Венеціанська комісія в п. 40 висновку щодо Польщі від 11-12 березня 2016 р. CDL-AD (2016) 001 зазначала: «<...> Саме установча влада, а не звичайний законодавець, покладає на Конституційний Трибунал (польський аналог конституційного суду - Г. Б.) компетенцію забезпечувати верховенство Конституції».

Отже, за відповідним підходом, устами конституційних судів якраз і проявляє себе установча влада, що зумовлює високий ступінь їхньої легітимності.

Іншої думки дотримується авторитетний дослідник демократії Р. Даль. Він уважає, якщо виходити з історії судового перегляду законів у США, судові піклувальники насправді не пропонують помітного захисту основоположних прав перед загрозою постійного їх порушення з боку всього демосу або його окремих представників. Як показує американський досвід, у демократичній країні, що використовує механізми квазіпіклування для захисту фундаментальних прав із боку законодавчих органів, ці механізми не є належною альтернативою демократичним процесам, хіба що в короткостроковій перспективі [19, с. 292-293].

Р. Познер на захист судового тлумачення в американському праві наводить такий аргумент: суди, особливо федеральні, з їх невиборними суддями, що довічно перебувають на посаді, незважаючи на безсумнівні обмеження щодо деяких можливостей, мають важливі переваги перед звичайними законодавцями. Вони загалом захищені від політичного тиску, якому піддається законодавчий орган, а цей тиск відображає часто егоїстичні і місцеві інтереси, небезпечні емоції, невігластво, ірраціональні страхи і забобони. Ця захищеність, разом із традиціями і звичаями судової професії і тим фактом, що федеральних суддів відбирають відповідно до їхньої компетентності та непідкупності, дає їм здатність до неупередженого і мудрого осмислення питань політики, що є цінним доповненням до розгляду тих питань звичайними законодавцями [5, с. 29].

Отже, у будь-якому разі варто визнати факт перетворення конституції шляхом її судового тлумачення. Варто завжди розуміти альтернативу, якою є розвиток конституції шляхом актів звичайного законодавця. Причому легітимність промовляти від імені установчої влади в законодавчої влади є значно меншою, 
ніж у конституційних судів, якщо поділяти підхід П. Розанвалона. Саме тому розвиток конституції шляхом її тлумачення не варто протиставляти концепції установчої влади.

\section{Jimepamypa}

1. Еллинек Г. Конституции, их изменения и преобразования. Санкт-Петербург: Право, 1907.118 c. Медушевский А.Н. Теория конституционных циклов. Москва : Изд. дом ГУ-ВШЭ, 2005. 576 с.

2. Розанвалон П. Демократична легітимність. Безсторонність, рефлексивність, наближеність. Київ : Вид. дім «Києво-Могилянська академія», 2009. 287 с.

3. Познер Р.А. Проблеми юриспруденції. Київ : Акта, 2004. 488 с.

4. Познер Р.А. Рубежи теории права. Москва : ВШЭ, 2016. 480 с.

5. Сліденко І.Д. Феноменологія конституційного контролю. Генеза, природа і позиціонування в контексті аксіологічних, епістемологічних, праксіологічних, синергетичних аспектів. Київ : Істина, $2010.624 \mathrm{c}$.

6. Хессе К. Основы конституционного права ФРГ. Москва : Юрид. лит., 1981. 368 с.

7. Прело М. Конституционное право Франции. Москва : Изд-во иностр. лит., 1957. 671 с.

8. Загальна теорія права / О.В. Петришин та ін. Харків : Право, 2020. 568 с.

9. Трудным путем демократии : Процесс государственного управления в США / К. Джанда и др. Москва : РОССПЭН, 2006. 655 с.

10. Таманага Б. Верховенство права. Історія. Політика. Теорія. Київ : Вид. дім «Києво-Могилян. акад.», 2007. $206 \mathrm{c.}$

11. Шмитт К. Политическая теология : сборник. Москва : Канон-пресс-Ц, 2000. 336 с.

12. Шевчук С.В. Способи тлумачення Конституції: порівняльний досвід. Конституція $i$ конституиіоналізм в Україні: вибіркові проблеми : збірник наукових праць. Київ : Купріянова, 2007. С. 33-57.

13. Шевчук С.В. Основи конституційної юриспруденції. Київ : Укр. центр правнич. студій, 2001. $302 \mathrm{c}$.

14. Сіган Бернард Г. Створення конституції для народу чи республіки, які здобули свободу. Київ : Ін-т демократії ім. П. Орлика, 1993.127 с.

15. Дворкин Р. О правах всерьез. Москва : РОССПЭН, 2004. 392 с.

16. Конституционая юстиция в станах Восточной Европы: проблемы теории и практики / отв. ред. Я. Залесны. Москва : Норма, 2020. 672 с.

17. Государственное право Германии. Москва, 1994. Т. 2. 320 с.

18. Даль Р. Демократия и ее критики. Москва : РОССПЭН, 2003. 576 с.

\section{Анотація}

Берченко Г. В. Розвиток конституції шляхом ії судового тлумачення та установча влада. - Стаття. Традиційно, коли говоримо про внесення змін до конституції, ми маємо на увазі трансформацію iї тексту. Проте було б надто формалістично вбачати конституцію в її текстуальному вираженні поза практикою застосування, тлумачення тощо. 3 огляду на доктринальні підходи, чинник тлумачення однозначно впливає на зміст конституції, а зміна вже сформованого тлумачення і поготів. На позначення впливу тлумачення на зміст конституції вживають різні терміни: «розвиток», «трансформація», «зміна» конституції.

Ключову роль у тлумаченні конституції в тих країнах, де існує модель спеціалізованого конституційного контролю, відіграють конституційні суди. Проте, як відомо, Конституційний Суд України відповідно до Конституції України здійснює низку повноважень, окремо зафіксовано повноваження щодо офіційного тлумачення Конституції України і щодо перевірки на відповідність Конституції України низки правових актів.

Варто було б ще раз звернути увагу на повноваження щодо офіційного тлумачення Конституції України шляхом його вдосконалення і прив'язки до конкретних практичних проблем правозастосування або ж відмовитися від нього взагалі. Тлумачення Конституційним Судом має здійснюватися, проте казуально - під час розгляду конкретної справи, шляхом конституційного контролю.

Відповідно до позиції Венеціанської комісії, устами конституційних судів якраз і проявляє себе установча влада, що зумовлюе високий ступінь іхньої легітимності. Отже, за будь-яких умов варто визнати факт перетворення конституції шляхом її судового тлумачення. Варто завжди розуміти аль- 
тернативу, якою є розвиток конституції шляхом актів звичайного законодавця. Причому легітимність промовляти від імені установчої влади в законодавчої влади є значно меншою, ніж у конституційних судів, якщо поділяти підхід П. Розанваллона. Саме тому розвиток конституції шляхом її тлумачення не варто протиставляти концепції установчої влади.

Ключові слова: конституційні суди, Венеціанська комісія, конституційний контроль, концепція відкритого тексту, легітимність.

\section{Summary}

Berchenko $H . V$. Development of the constitution by its judicial interpretation and constituent power. - Article.

Traditionally, when we talk about amending the constitution, we mean the transformation of its text.

However, it would be too formalistic to see the constitution in its textual expression outside the practice of application, interpretation, and so on. Given the doctrinal approaches, the factor of interpretation clearly affects the content of the constitution, and the change of the already formed interpretation - even more so. Different terms are used to denote the influence of interpretation on the content of the constitution: development, transformation, change of the constitution.

Constitutional courts play a key role in interpreting the Constitution in countries where there is a model of specialized constitutional review. However, as is well known, the CCU exercises a number of powers in accordance with the Constitution of Ukraine, with separate powers regarding the official interpretation of the Constitution of Ukraine and the verification of a number of legal acts for compliance with the Constitution of Ukraine.

It would be worthwhile to pay attention once again to the authority to officially interpret the Constitution of Ukraine by improving it and linking it to specific practical problems of law enforcement, or to abandon it altogether. Thus interpretation by the Constitutional Court should be carried out, however casually, - at consideration of a concrete case by the constitutional control.

According to the position of the Venice Commission, it is precisely the constituent power that manifests itself through the mouths of the constitutional courts, which determines a high degree of their legitimacy. Thus, in any case, it is necessary to recognize the fact of transformation of the constitution by its judicial interpretation. It is always necessary to understand the alternative, which is the development of the constitution through the acts of the ordinary legislator. Moreover, the legitimacy of the legislature to speak on behalf of the constituent power is much less than that of the constitutional courts, if we take the approach of P. Rosanvallon. That is why the development of the constitution through its interpretation should not be contrasted with the concept of constituent power.

Key words: constitutional courts, Venice Commission, constitutional review, concept of open text, legitimacy. 